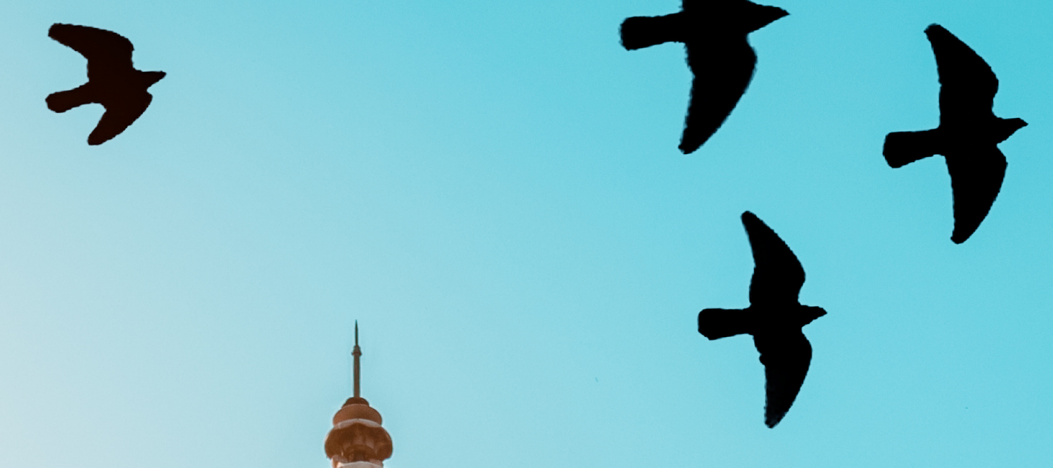

4
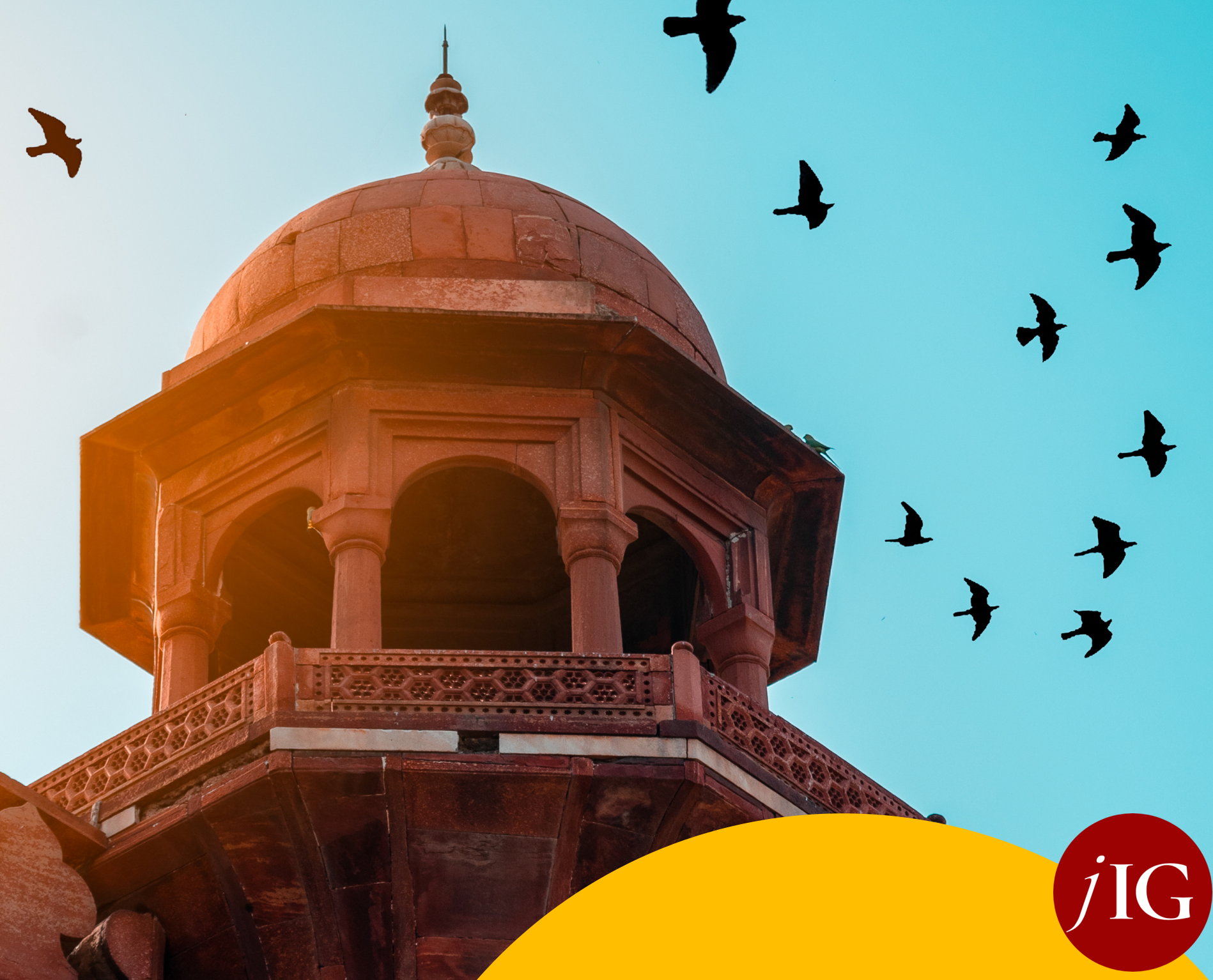

\title{
The Culture of
} Technologicol Greotivity in the lslamic World during the First Islomic Colden Age

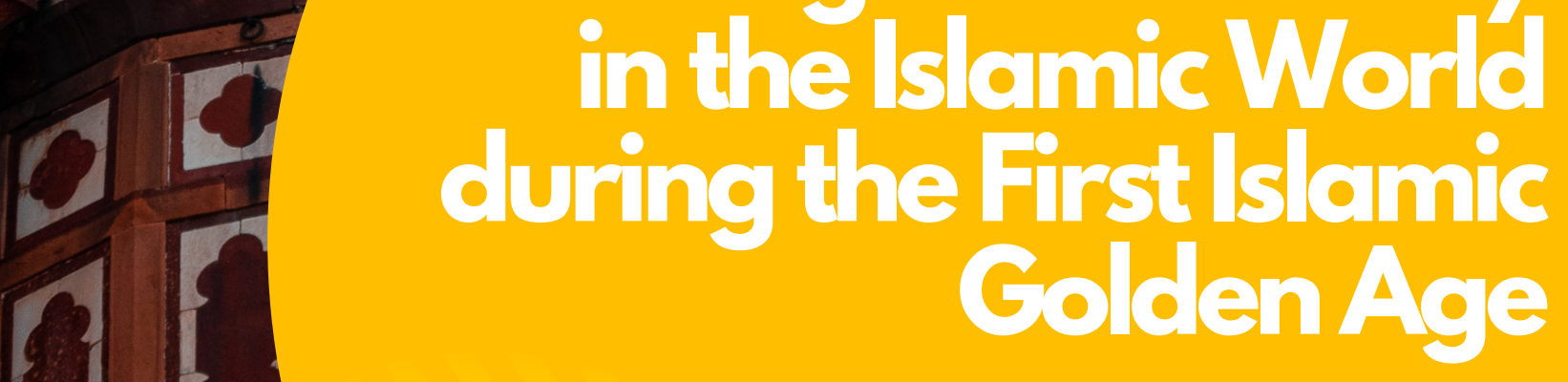
2)

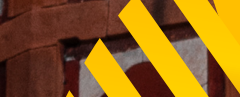

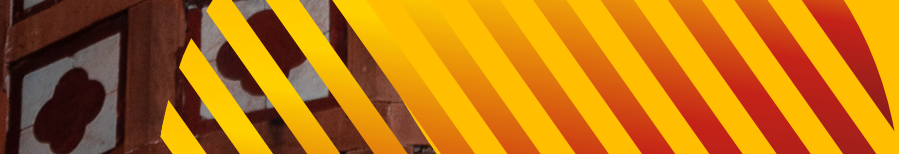

BY LIM REN CHONG 


\title{
The Culture of Technological Creativity in the Islamic World during the First Islamic Golden Age
}

\author{
Lim Ren Chong ${ }^{1}$
}

\begin{abstract}
The Islamic world in the period between 132AH/750AD - 655AH/1258AD is marked by technological advancements stemming from the ability of its community to preserve, adapt and build on already existing knowledge assimilated from others. There was a culture highly creative in its approach to driving technological progress, which led to the development of valuable innovations and the accumulation of vast wealth. More importantly, these innovations enabled the community to achieve the Maqāșid. Leadership, stable rules of law, common trade rules, effective administration, and strong institutions are some of the ingredients giving rise to a culture of technological creativity. An often-underrated essential ingredient is the communication of information. Knowledge codified as information in patents, journal articles, and book chapters is only useful when it is efficiently communicated to individuals who can transform the information into innovations. During this golden age, there were many individuals involved with the delivery and exchange of information. NonMuslim members within the community-made notable contributions, particularly in translating non-Arabic scientific works into Arabic. Later generations of Muslim innovators made extensive use of these translated works which included insightful dialectical commentaries.
\end{abstract}

Keywords: Innovation culture, technological creativity, Islamic golden age, information communication, knowledge production

1 Correspondence author. The author is an Assistant Professor at Centre for Advanced Material and Energy Sciences, Universiti Brunei Darussalam. renchong.lim@ubd.edu.bn 
$\mathrm{T}$

he Islamic world during the first Islamic golden age was a civilisation in which many technological advancements took place. The main constituent of this Islamic civilisation was its highly creative community capable of preserving, adapting, and build on already existing knowledge assimilated from other civilisations. Many existing Islamic inventions and architectures are a result of innovations developed through such endeavours. The objective of the community ${ }^{1}$ was clear and motivated by theological impulses. More specifically, the community aimed to sustain and preserve its standards of living, as well as to carry out its obligations in line with humanity's main responsibility in this world as revealed in Sūrah Adh-Dhāriyāt 51:56.

The main reason for studying technological creativity is to develop a framework in which we can manage technological disruption and ensure that any scientific advancements made are aligned with the theological principles of Islam. The first Islamic golden age can offer us guidance on how early Muslims made use of scientific advancements and technological progress to achieve the Maqāșid. Significant technological progress took place in diverse areas such as agriculture, irrigation, military engineering, civil engineering, timekeeping, navigation, and medicine. These achievements are results of advancements made in the physical sciences such as mechanics and astronomy, health sciences as well as mathematics.

One notable breakthrough during this period was the publication of a book titled al-Kitāb alMukhtașar fi Hisāb al-Jabr wāl-Muqābalah (The Book of Compendium of Algebra and Balancing for Accounting) by Muhammad ibn Mūsa al-Khwārizmi around 203AH/820AD which led to the development of algebra as an essential part of mathematics. Latinised versions of Al-Khwārizmi's name lend themselves to the word "algorithm" widely used in the context of one general-purpose technology (GPT) underpinning the ongoing Fourth Industrial Revolution (IR4.0). ${ }^{2}$ Technological changes under IR4.0 are disrupting the workplace, putting the future of many existing jobs under threat.

I will begin by qualifying the 'Abbāsiyah period between 132AH/750AD - 655 AH/1258AD as the first Islamic golden age due to the technological progress and scientific advancements achieved which were largely supported through patronages from its leadership and ruling

\footnotetext{
1 The definition of community includes both Muslims, and non-Muslims who align with the theological principles of Islam.

2 Manuel Trajtenberg, "Al as the next GPT: a political-economy perspective," NBER Working Paper No. 24245, January 2018, https://doi.org/10.3386/w24245.
} 
elites. This is followed by the identification of the ingredients making up a culture of technological creativity. Innovations and achievements of scholars in the physical and medical sciences, mathematics, and engineering during the 'Abbāsiyah period are also highlighted. The role of information communication will be emphasised as an essential ingredient for this culture. Non-Muslims in the community dynamically engaged in activities relating to information exchange especially through translation owing to their knowledge of non-Arabic languages. The abrupt decline of this culture for the 'Abbāsiyah caliphate and the end of the first Islamic golden age can be attributed to an exogenous event, the Siege of Baghdād, in 655AH/1258AD.

My final section will be devoted to highlighting the role of the sciences (translated as 'ilm in Arabic) $)^{1}$ in producing innovations within the Maqāșid framework. This may offer guidance for integrating Islamic concepts within contemporary society. These insights can be useful for managing disruption to the workplace and protecting the future of existing jobs through taking charge of the scientific advancements underpinning this technological change from a theological perspective. Our guiding principle moving forward must be aligned with the theological principles of Islam and scientific developments to support new technologies that cannot deviate from this path.

\section{The 'Abbāsid Period as the First Islamic Golden Age}

Golden ages are often associated with sustained periods of technological and economic progress. Civilisations experiencing a golden age will accumulate vast amounts of wealth to support scholarly efforts and take on massive infrastructure projects such as the construction of megacities of their times. One qualifying period for the Islamic world is the 'Abbāsiyah period between 132AH/750AD - 655AH/1258AD. It was a long period of stability that allowed technological creativity to flourish. The centre of the administration and major place of learning for most of this period was Baghdād where the city foundations were laid down by the second 'Abbāsiyah Caliph al-Manșūr (136AH/754AD - 158AH/775AD).

\footnotetext{
Development of the sciences ('ilm) in the Islamic world were adapted and modified using ideas and techniques developed in the Sasanian, Byzantine, and Hellenistic civilisations, as well as influences from India and China. Even though the Islamic community took an encyclopaedic view of knowledge, in a similar manner to the Greeks, various classification of knowledge or the sciences into specific disciplines were conscientiously compiled during the early translation movement of non-Arabic works to Arabic. The scientific disciplines were not strictly limited to the physical sciences, health sciences and mathematics which we are familiar with in the contemporary context, but also disciplines such as theology, philosophy, logic, metaphysics, and mysticism. The origins of the word "science" come from the Latin words "scientia", from "scire" in which the latter can be translated as "know". Science and knowledge are thus closely linked in its etymology, a relationship which is preserved in its Arabic form 'ilm.
} 
The 'Abbāsiyah Caliphate embraced a heterogeneous and cosmopolitan community united under the protection of the Arab caliphate and the guidance of Islam. ${ }^{1}$ Although the preceding 'Umawiyah Caliphate was primarily concerned with military affairs and the pacification of occupied lands, they set up much of the administrative, fiscal, and legal systems which the 'Abbāsiyah leadership adopted. Arabic became the lingua franca even though Arabs were only a minority because of the integration of massive numbers of nonArabs into the community through expansion. The Arabs remained the ruling elites for the majority of this period, but their political authority waned as power transferred to Turkish and Mamlük military commanders in a process which took place gradually over the centuries.

Under the leadership of 'Abbāsiyah caliphs, the overall character fostering knowledge of the sciences was diverse in both ideas and participation as well as cosmopolitan. The integration of the cultural achievements of all members in the Islamic community was highly regarded by the caliphs and they saw it as a central mission of the dynasty. ${ }^{2}$ The ruling elites actively sponsored scholarship as well as translation of scientific works into Arabic, in particular Greek works available in late antiquity. ${ }^{3}$ These works covered various disciplines such as astrology, alchemy, physics, botany, and medicine which were not widely available in the Islamic world near the beginning of the 'Abbāsiyah period. Such activities made information required for any form of scientific advancement easily accessible and available in Arabic.

Support from the leadership was evident through institutionalising these translating efforts. As an example, Caliph Hārūn ar-Rashīd (148AH/786AD - 193AH/809AD) built a library, Khizānat al-Hikmah (Storehouse of Wisdom), to accommodate large collections of Greek manuscripts and books. Following this, Caliph al-Ma'mūn (198AH/813AD - 218AH/833AD), son of Caliph Hārūn ar-Rashĩd, established one of the most famous institutions of knowledge, the Bayt al-Hikmah (House of Wisdom). This was a far more ambitious institutional undertaking compared with that of his father as the institution went beyond translating only non-Arabic works. Bayt al-Hikmah resembled a research institute where translations, as well as original scientific research and development, were carried out. ${ }^{4}$

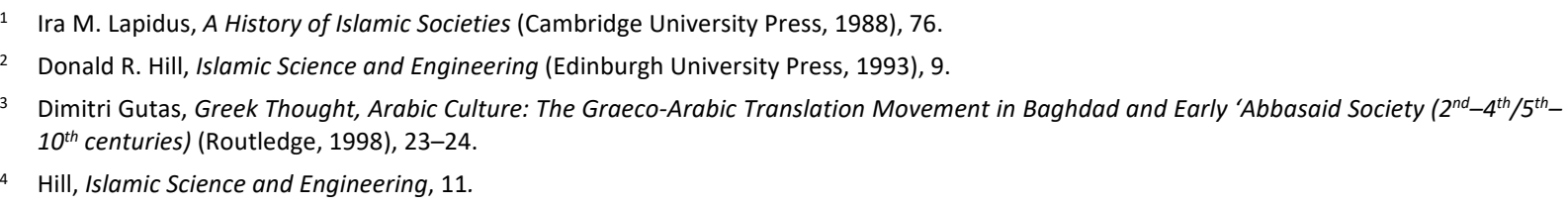


Patronages of scientists and scholars housed in these institutions were commonly practised to support these intellectual endeavours.

The pursuit of knowledge of the sciences flowered during the 'Abbāsiyah times. The translations sponsored by the leadership provided the foundations for a continuous process of innovation, research, and development. Later generations of Islamic scientists and engineers made extensive use of translated works from their predecessors instead of the original non-Arabic sources. As a result, the advancements made were a blend of both nonArabic and Muslim thoughts. Naturally, this blend achieved an alignment of non-Arabic thoughts with the theological principles of Islam.

\section{Ingredients for a Culture of Technological Creativity}

One useful background to technological creativity was provided by a 20th century AD American economic historian, Joel Mokyr, who was interested in the fundamentals behind how some nation-states become rich whilst others remain poor. ${ }^{1}$ He noted that the main difference between rich and poor nations is not that the rich have more money than the poor, but that rich nations can produce more goods and services enabled by a range of more superior technologies. His work echoes that of an 18th century AD Scottish economist, Adam Smith, ${ }^{2}$ but significantly different through the incorporation of contemporary economic ideas developed in the 20th century AD.

In Mokyr's analysis, economic growth and progress are a result of four distinctive processes. The first process relates to capital investment as a means of increasing productivity of labour which he called Solovian growth, in honour of Robert Solow, who laid the foundations for the modern theory of economic growth. ${ }^{3}$ An increase in productivity can be sustained through the capital investment so that each worker has access to a more and better quality of equipment and tools. The second process is called Smithian growth derived from ideas developed by Adam Smith. Finer division of labour leads to productivity growth through specialisation and the adaptation of skills to tasks. Specialisation at the individual level collectively leads to an improvement in national comparative advantage which increases revenue generation from cross-border trade. Free-trading activities between nation-states

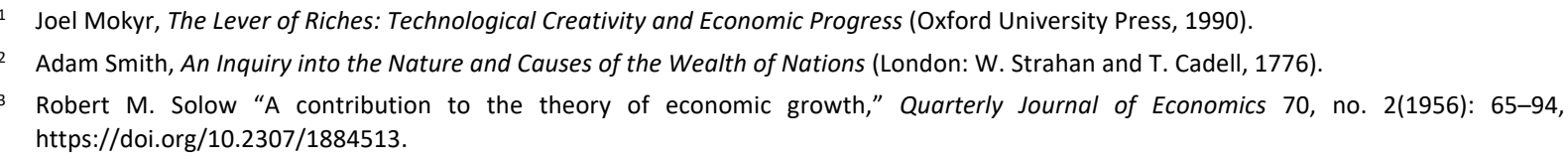


are strongly encouraged to develop such specialisations and adaptations. A third process is a form of economic growth due to increasing population size. The consumption of goods and services rises as the size of the market increases, resulting in a thriving and dynamic economy.

Finally, a process relating an increased stock in human knowledge to technological progress and institutional changes called Schumpeterian growth was outlined. It draws heavily from ideas developed by a 20th century AD Austrian political economist, Joseph Schumpeter, famous for developing the concept of "creative destruction". In this pioneering idea, Schumpeter noted the strong role of innovation and entrepreneurship in any form of economic activity. ${ }^{1}$ Creative destruction lends itself to this idea of a flux of change as we innovate to remain relevant and sustainable with time.

A notable evolution of Schumpeter's ideas, not covered by Mokyr, is a concept of individuals called innovative entrepreneurs developed by William Baumol. ${ }^{2}$ The innovative entrepreneur is different from the replicative entrepreneur in that this individual comes up with new ideas and immediately puts them into practice as opposed to one launching a new business venture where similar ventures already exist. Baumol's ideas on this front remain niche and have yet to catch the attention of mainstream economics research due to difficulty in defining and quantifying the output of innovative entrepreneurs.

Culture, according to a 19th-century English anthropologist, Sir Edward Burnett Tylor, is a complex whole that includes knowledge, belief, art, morals, law, custom, and any other capabilities and habits acquired by man as a member of society. ${ }^{3}$ Society is understood to take on the same meaning as a community where man comprises both female and male members of the community. Tylor's definition offers an indication of the different ingredients making up culture and notable sets of attributes include knowledge, law, and custom. In order to be more specific about these attributes, we can make use of Mokyr's observations of attributes found in nation-states having technological creativity. He found that common attributes prevalent in rich nation-states include clear leadership, a stable rule of law,

\footnotetext{
Joseph Schumpeter, The Theory of Economic Development: An Inquiry into Profits, Capital, Credit, Interest, and the Business Cycle, trans. Redvers Opie (Harvard University Press, 1934).

2 William J. Baumol, The Microtheory of Innovative Entrepreneurship (Princeton University Press, 2010).

3 Edward B. Tylor, Primitive Culture: Researches into the Development of Mythology, Philosophy, Religion, Art, and Custom (London: John Murray, 1871).
} 
effective administration, and strong institutions. Most of these attributes have already been discussed within the context of Islamic governance. .,2,3 $^{1,3}$

There are other attributes that can be included while also taking into account contemporary considerations such as the proliferation of cross-border trading activities and power dynamics inherent to international relations. ${ }^{4}$ These attributes are knowledge-pursuing qualities, the efficient dissemination of information, and common trade rules. Knowledgepursuing qualities refer to the volition towards learning, creation, and preservation of knowledge. Codified knowledge in the form of information is valuable when it is communicated to an individual who can make use of that knowledge. Moreover, innovation is a product of information and knowledge. ${ }^{5}$ Efficient means of communicating information as well as the promotion of activities through information sharing and exchange using safe and secure platforms can accelerate the pace of innovation.

Lastly, common trade rules refer to establishing trade agreements between nation-states in areas such as the protection and enforcement of trading rights as well as the manner in how trading disputes can be resolved. Multilateral organisations and nation-states organised within trading blocs play important roles in shaping these rules which can include product certification of origin, regulation of services, and administration of intellectual property rights. Market-based trading also offers an efficient platform for sharing and exchanging information.

\section{Innovation and Achievements in the Sciences during the 'Abbāsiyah Period}

The establishment of Bayt al-Hikmah and Khizānat al-Hikmah in Baghdād by two 'Abbāsiyah Caliphs demonstrates the relevance of some of the cultural ingredients mentioned previously: namely leadership, strong institutions, and knowledge-pursuing qualities. The leadership recognised the importance of learning, creation, and preservation of knowledge for the community and saw to it that these institutions were set up during their respective

\footnotetext{
1 Amin Abdul Aziz, “Governance in a Contemporary Islamic Negara," Journal of Islamic Governance (2015), islamicgovernance.org/jig1-p1.

2 Rozan Yunos. "The Evolution of Islamic Governance: With Special Reference to Brunei Darussalam," Journal of Islamic Governance (2017). islamicgovernance.org/jig3-p1.

3 Iznan Tarip, “'Darkness to Light' in Islamic Corporate Governance," Journal of Islamic Governance (2020), islamicgovernance.org/jig5-p1.

4 A short discourse on the power dynamics inherent to international relations can be found here: Majdey Zawawi. "Towards a Maqāșidic Approach to Power Currencies, Thought Paper Series No. 3." Journal of Islamic Governance (2020), islamicgovernance.org/tp3.

5 Kenneth Arrow, "Economic Welfare and the Allocation of Resources for Invention," in The Rate and Direction of Inventive Activity: Economic and Social Factors, ed. Universities-National Bureau Committee for Economic Research, Committee on Economic Growth of the Social Science Research Council (Princeton University Press, 1962), 609-626, http://www.nber.org/chapters/c2144.
} 
rules. These institutions became highly reputable repositories of information and hosted many scientists and scholars through patronages by notable figures in the 'Abbāsiyah court.

Baghdād became an important centre of learning as well as innovation activities during the first Islamic golden age. Viewed through a contemporary lens, one would describe Baghdād as an innovation hotspot that is a centre of innovation activities connected to a cross-border network of innovation ecosystems. ${ }^{1}$ Innovation hotspots greatly contribute to their respective domestic economies as well as the other economies to which they are connected. They largely leverage the efficient dissemination of information made possible using the latest information communications technologies (ICT) and knowledge institutions based inside them.

Besides the existence of these iconic establishments found in Baghdād, institutions such as mosques having libraries were commonplace in the Islamic world. The mosque was always a centre of learning and institutions such as the madrasah grew from these humble beginnings. These institutions further grew to become early universities across the Islamic world which preceded the medieval universities established in Latin Europe. During this golden age, there were several major centres of learning in the Islamic world other than Baghdād. For example, the Fatimids set up the Dār al-Hikmah (Abode of Wisdom) based in Cairo. $^{2}$ Other examples include the al-Azhar in Cairo, the Zaytuniyya in Tunis, and the Qarawiyyin in Fez.

Inventions are physical forms of innovations that can be used in combination with other types of innovation to create value. Contemporary economics often describe innovation and valuecreation strictly in monetary terms because of the objectivity one can achieve through measuring monetary outputs. ${ }^{3}$ However, value-creation need not be strictly limited only to monetary terms. In general, members within any community can develop innovations aligned with the Maqāșid. The Maqāșid framework outlines five forms of value: the promotion and preservation of the Dinn, life, intellect, progeny, and wealth. Within this framework, wealth creation is only one out of five forms of value. A holistic approach towards value-creation within this framework is one that takes into consideration all five forms of value. This

\footnotetext{
1 WIPO. World Intellectual Property Report 2019: The geography of innovation: Local hotspots, global networks (Geneva: World Intellectual Property Organization, 2019), https://www.wipo.int/edocs/pubdocs/en/wipo_pub_944_2019.pdf.

2 Al-Hassan \& Hill, Islamic Technology, 11.

3 The CORE team, The Economy (Oxford University Press, 2017), Unit 21: Innovation, information, and the networked economy, https://www.core-econ.org/the-economy/book/text/21.html.
} 
approach ensures that the innovations developed and associated technological progress are in alignment with the theological principles of Islam.

Some of the best-documented inventions during the early 'Abbāsiyah period were made by the Banu Mūsa brothers in the 2nd century AH who published a book titled Kitāb al-Hiyal (Book of Machines). The Banu Mūsa brothers became wards in the court of Caliph alMa'mūn upon their father's death, Mūsa ibn Shākir, a renowned astronomer and close companion of the caliph. ${ }^{1}$ The brothers in order of seniority, Muhammad, Ahmad, and alHasan, were enrolled and educated at Bayt al-Hikmah. They later carried out engineering activities for the Caliph which included geodetic surveys and public works.

Under the Caliph's patronage, the brothers oversaw the collection of non-Arabic works and wrote many books. Muhammad was known to make a journey to Byzantium in person to seek out relevant Greek works while Kitāb al-Hiyal was largely based on the efforts of Ahmad. This book described the mechanics behind machine-like inventions and was known to supersede the works of their Greek predecessors. Nonetheless, this work suffered from the unsuccessful attempts of later innovators to improve upon their results. This was attributed to the fact that the theoretical geometrical proofs used to explain the machines can be difficult to follow. ${ }^{2}$

In the 6th century $\mathrm{AH}$, Ismā't ibn ar-Razāz al-Jazari followed-up the works of his predecessors with the publication of a book titled Kitāb fi Ma'rifah al-Hiyal al-Handasiyah (The Book of Knowledge of Mechanical Machines). ${ }^{3}$ In this book, he criticised the reproducibility of theoretical designs which cannot be experimentally verified. This is a clear demonstration of a dialectical discourse between these two major works. Experimentation and reproducibility are fundamental to contemporary physical sciences. Al-Jazari preceded the development of contemporary physical sciences and had conceived these empirical approaches in his time through a dialectical method. He is acknowledged to have performed these endeavours under the theological principle behind the promotion and preservation of the intellect.

\footnotetext{
1 Hill, Islamic Science and Engineering, 11-12.

2 Ibid, 123. This statement was adapted from Ibn Khaldūn's commentary on the works of the Banu Mūsa brothers. It is also worth noting that even though geometrical proofs can be hard to follow, the Arabic polymath and philosopher, al-Kindi, used mathematics to achieve some degree of certainty in his arguments and convictions. See Gutas, Greek Thought, Arabic Culture, 120.

3 Al-Hassan \& Hill, Islamic Technology, 15-16.
} 
Composite energy-transforming machines to carry out useful work formed some of the bestdocumented innovations during 'Abbāsiyah times. The most common examples made use of the transformation between gravitational potential energy and physical energy to kinetic energy. Such machines were used to transfer water from wells or other sources for use in drinking, irrigation, and various industrial purposes. An example is one variant of the sāqiya ${ }^{1}$ called the Pump and the Fake Cow. ${ }^{2}$ This composite machine was powered using the kinetic energy of flowing water to rotate a series of connected gears and wheels which transported water to a different height. The fake cow has been employed in this design to prove the point that this variant was different from previous designs which made use of live animals.

Translating activities played an important role in fostering a culture of technological creativity during the first Islamic golden age. The translation of non-Arabic works into Arabic lowered the barrier to accessing information for individuals in the community. Early Muslim scholars were interested in mathematics, astronomy, mechanics, engineering, and philosophy. They made use of knowledge already developed and maintained by the Sasanian and Indian civilisations to the East, as well as the Hellenistic and Byzantine civilisations to the West. Key mathematical texts which were translated included Euclid's Elements and Nichomachus' Introduction to Arithmetic. The most iconic text on astronomy was Ptolemy's Almagest while that of mechanics is Mechanics by Hero of Alexandria. Other notable engineering texts translated included works by Archimedes and Philo of Byzantium. Finally, Aristotle's Physics was highly influential in shaping the thoughts of early Muslim scientists and scholars in natural philosophy. ${ }^{3}$ The knowledge from the Greeks provided much of the foundation from which further research and development in different disciplines could take place.

Patronage of both non-Arabs and non-Muslim Arabs to support these translation efforts were commonplace due to their extensive and specialised knowledge of various non-Arabic languages. ${ }^{4}$ One of the first translators was a Persian scholar, Ibn al-Muqaffa', in the court

\footnotetext{
1 The sāqiyah is a machine comprising gears and wheels often used as water-raising machines. It was widely used by the Romans and is believed to be invented in Hellenistic Egypt (also known as Ptolemaic Egypt). The sāqiyah superseded the shādūf whose usage can be traced back to Akkadian times. See Hill, Islamic Science and Engineering, 92-94.

2 Al-Hassan \& Hill, Islamic Technology, 43-45.

3 Natural philosophy came to be known as 'ilm al-țabī'i based on works by Ibn Rushd (Averroes) in the late 'Abbāsiyah period. See Gerhard Endress, "Mathematics and Philosophy in Medieval Islam," in The Enterprise of Science in Islam: New Perspectives, eds., Jan P. Hogendijk, and Abdelhamid I. Sabra (The MIT Press, 2003), 121-176.

4 The most common non-Arabic languages found in written works during the 'Abbāsiyah period were Pahlavi (also known as Middle Persian), the Semitic Syriac language, Byzantine Greek and Classical Greek.
} 
of Caliph al-Manșūr. ${ }^{1}$ He translated an Indian book of fables known as Kalīlah wa-Dimnah which was available in the Pahlavi language. ${ }^{2}$ This is one example of many original works in Sanskrit which made their transition into Arabic through intermediate Pahlavi translations and Persian scholars. ${ }^{3}$

Arab scientists and non-Arab translators under the early 'Abbāsiyah court often worked together. As an example, the Banu Mūsa brothers collaborated extensively with a Șāba'in scholar well-versed in Greek and Syriac from Harrān, Thābit ibn Qurah. ${ }^{4}$ He translated many Greek works on mechanics and engineering as well as mathematical subjects such as geometry and arithmetic. After leaving the employment of the Banu Mūsa brothers, Thābit ibn Qurah became court astrologer to the Caliph al-Mu'tadid (279AH/892AD 289AH/902AD). Under this new patronage, he continued to translate Greek works on astronomy, corrected previous Arabic translations, and commented on the philosophically inclined Aristotelian physics.

One of the most prolific translators in the early years of the caliphate was Hunayn ibn 'Isḥāq, a Nestorian Christian Arab scholar originating from al-Hirah close to the Euphrates in southern Iraq. ${ }^{5}$ His most important contribution was a translation of one hundred and twenty-nine medical treatises by Galen in a magnum opus famously known as Risālah Hunayn. ${ }^{6} \mathrm{He}$ taught and collaborated with his son Iș̣āq and nephew Hubaysh whose names are commonly associated with translators found in the early 'Abbāsiyah court based in Baghdād. Their translated efforts were transcribed and translated into Latin around the 6th century AH (12th century AD) before making their way into medieval European scholarship. ${ }^{?}$

Cultivation of the sciences during 'Abbāsiyah times was championed by the Arabic polymath and philosopher, Abu Yūsuf Ya'qūb ibn 'Ishāa al-Kindi. ${ }^{8}$ He promoted the study of the

\footnotetext{
For those interested in early Islamic political thought, Ibn al-Muqaffa' was a secretary who served under both the 'Umawīyah and 'Abbāsiyah caliphates. He articulated the concept of moral refinement in the 'Abbāsiyah court known as adab and wrote extensively on matters related to Islamic polity. His Risala fi'l-sahaba is widely known as the first legal theory of governance in the Islamic world. See Anthony Black, The History of Islamic Political Thought: From the Prophet to the Present (Edinburgh University Press, $2^{\text {nd }}$ Edition, 2011), $20-24$.

2 Hill, Islamic Science and Engineering, 10.

3 A preceding translation movement took place in the Sasanian civilisation in an attempt of reclaiming Persian knowledge which was lost after the Macedonian king, Alexander the Great, conquered the Old Persian Empire, had all existing Persian knowledge translated into Greek and then destroyed all information available in Persian. See Greek Thought, Arabic Culture, 36-41.

4 Hill, Islamic Science and Engineering, 11-12.

5 Gutas, Greek Thought, Arabic Culture, 14.

6 Max Meyerhof, "New Light on Hunain Ibn Ishaq and His Period" Isis 8, no. 4(October 1926):685-724, https://www.jstor.org/stable/223871.

7 Hill, Islamic Science and Engineering, 221.

8 Gutas, Greek Thought, Arabic Culture, 88.
} 
sciences, in particular philosophy, amongst his circle of scientists and collaborators. ${ }^{1}$ Caliph al-Mu'tașim (218AH/833AD - 227AH/842AD) who succeeded Caliph al-Ma'mūn and appointed al-Kindi as tutor to his son Prince Ahmad. Many of al-Kindi's activities were made possible through the patronage of the Prince. A research programme was initiated to acquire, and complete the Greek sciences aimed at advancing knowledge instead of repeating information through rote memorisation.

Al-Kindi pursued such endeavours because he was interested to apply knowledge of the Greek sciences in theological and religious discussions. Given the accessibility of information found in translated texts, recourse to such works for solutions to intellectual problems was practised by al-Kindi's circle in Baghdād. The reason was thus used as a tool to resolve prevalent issues at the time and was never used to oppose faith. By using reason in this manner, al-Kindi and his peers were able to maintain the theological principle behind the promotion and preservation of both Din and intellect. This practice is evidence that faith and the sciences can work hand in hand and not in opposition or conflict with one another. Much of al-Kindi's activities were related to the alignment behind scientific thoughts with the theological principles of Islam.

In addition to Prince Aḥmad's patronage of philosophical works, the Prince was a patron to a notable Melkite Greek Christian translator and scholar, Qusța ibn Lūqa, from the town of Ba'labak located in Wādi al-Biqā', Lebanon. ${ }^{2}$ The Prince commissioned the translation of various Greek works on mathematics, astronomy, and mechanics. Independently, Qusța ibn Lūqa wrote several original theses on medicine and commented on the disciplines of mathematics, astronomy, mechanics, and engineering. This is another example of the promotion and preservation of the intellect widely promoted through patronages by the ruling elites within the 'Abbāsiyah court.

Achievements in mathematics were highly remarkable during this period. Like the development of the physical and health sciences, advancements made in mathematics built on knowledge acquired from preceding scholars in this area, most notably from the Greeks as well as Indian sources through Pahlevi intermediaries. One of the landmark breakthroughs was the development of algebra by Muhammad ibn Mūsa al-Khwārizmi, a scholar employed

\footnotetext{
Ibid, 119-120.

2 Gutas, Greek Thought, Arabic Culture, 125.
} 
in the court of Caliph al-Ma'mūn and hosted at Bayt al-Hikmah. ${ }^{1}$ He also wrote extensively on arithmetic and geometry. Surviving theses on these mathematical topics are available through Latin translations as some of his original Arabic works have yet to be found. ${ }^{2}$ Many of his mathematical advancements paved way for further research and development in several other disciplines including astronomy, mechanics, and engineering as well as jurisprudence. For instance, a significant proportion of his original thesis on algebra was dedicated to practical matters such as the balancing of payments concerning trade, inheritances, and matrimony.

Translation of Greek and Pahlevi mathematical and astronomical works provided much of the foundation for research and development in astronomy in the Islamic world. Muslim scientists and scholars took a primary interest in this discipline because this specialised knowledge was used to define times for praying, one of the main obligations in relation to the promotion and preservation of the Din. Prayer times were determined based on the position of the sun in the sky relative to the local horizon. Furthermore, combining astronomical and geographical knowledge alongside geometry from mathematics revealed the qiblah, the direction for prayer towards al-Ka'bah in Makkah. Also, this collection of knowledge was used to predict the visibility of the lunar crescent which defined the beginning of the lunar months based on a criterion adapted from Indian astronomy. ${ }^{3}$ This was a useful skill to acquire especially for application during nights when lunar visibility can be obscured due to the presence of large clouds or heavy rain.

The origins of Indian influences in astronomy can be attributed to a delegation from Sind carrying a set of Sanskrit texts related to this discipline, a siddhānta, to the court of Caliph Caliph al-Manșūr in 154AH/771AD or 156AH/773AD. ${ }^{4}$ The Caliph appointed an Arab astronomer, Ibrāhīm al-Fazāri, to translate this work who collaborated his son, Muhammad, and a Persian, Ya'qūb Ibn Țāriq. ${ }^{5,6}$ They published the Zij al-Sindhind al-Kabīr (Great Astronomical Tables of the Sindhind) which not only introduced Indian astronomy to the

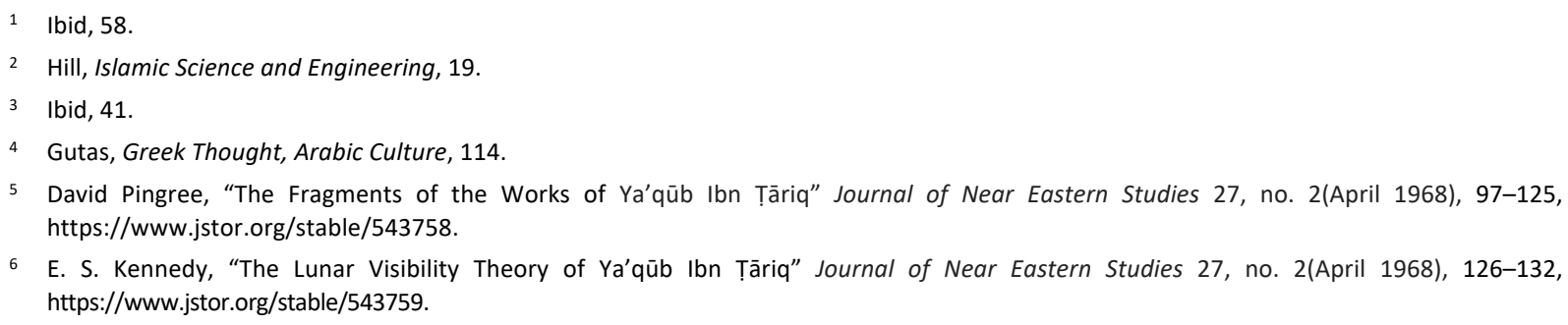


Muslim scholars but also the Hindu numerical system. ${ }^{1}$ Later, al-Khwārizmi followed-up with original contributions to this work while Ișhāa ibn Hunayn and Thābit ibn Qurah were respectively involved in translation and correction efforts about Ptolemy's Almagest. ${ }^{2}$ These collective efforts sparked the spectacular development of astronomy in the Islamic world.

Physical machines using fine mechanical technology called astrolabes were developed and used by astronomers during this period. ${ }^{3}$ An astrolabe is an instrument physically capable of projecting three-dimensional information onto a two-dimensional plane. The ability to conceive and fabricate such an intricate device demonstrates the skill level of innovators in transforming and adapting mathematical concepts to the physical world. Innovators in early medieval Europe were known to use a Latin translation of an Arabic thesis on the astrolabe by Ma Shā' Allāh ibn Athari, a Persian Jew from Bașrah and court astrologer during the reigns of Caliph al-Manșūr and Caliph al-Ma'mūn. ${ }^{4}$ Much of the knowledge transfer to early medieval Europe originated from Latin translations of Arabic works. Commentaries made in Arabic works were very much relevant and useful to innovators in early medieval Europe as they continued to build on the new knowledge created in the Islamic world.

Innovation-related activities naturally flourished and became widespread across the Islamic world as translated works reached far and wide. The availability and accessibility of information found contained within these works contributed to major developments in the sciences alongside different technological advancements not mentioned here. The innovations produced using these scientific advancements can appear in the form of new knowledge codified as information in these works. Later generations of innovators made use of these translated works which included dialectical commentaries explaining adaptions and modifications made to the original ideas. Such insightful commentaries contextualised the changes made to accommodate the time and place of writing. Above all, the number of Muslim innovators across the Islamic world increased because these communal efforts lowered the barrier of access to information containing useful knowledge for achieving the Maqāṣid.

\footnotetext{
1 Hill, Islamic Science and Engineering, 16.

Ibid, 33-34.

Ibid, 48-52.

Ibid, 223-224
} 


\section{Information Communication during the 'Abbāsiyah period}

Information is the codified expression of knowledge. Examples of literary information include patents, journal articles, book chapters, theses, and reports. In the contemporary context, information can appear in digital forms such as those found in apps, websites, and social media platforms easily accessible using smartphones, laptops, and desktop computers. More importantly, information can be recognised as a trading commodity within the context of knowledge-based economies. ${ }^{1}$ According to Mokyr, technological progress can be observed as the efficient application of information to the production of knowledge. In other words, the creation of new knowledge and information using fewer resources. The production of valuable innovations takes place when information arrives at individuals within the community who can use the knowledge. Hence, the delivery of information, supported using leading communications technology, is an essential ingredient for any culture supporting technological creativity.

During the 'Abbāsiyah caliphate, a postal-based information communication system called the Barĩd was extensively used for transporting official correspondences. ${ }^{2}$ This system was modified and adapted from an earlier communication network developed by Persian rulers of the Sassanid dynasties. An auxiliary courier service was also offered which provided information about local circumstances. The Barīd became a very important institution that provided effective administration by easing the flow of official correspondences and local information across the caliphate. This innovation facilitated governance over long distances.

Dissemination of information was more efficient and accessible using paper instead of papyrus and parchments which were fragile as well as expensive. Paper became the primary medium for storing information in the Islamic world during this time. The introduction of papermaking technology is believed to have originated from Chinese prisoners of war captured after the Battle of Talas between the armies of the Chinese Tang Dynasty and those of the 'Abbāsiyah caliphate in 133AH/751 AD. ${ }^{3}$ Some decades after the battle, a paper mill was founded in Baghdad some decades presumably to meet the high demand for paper as a strong intellectual culture began to take hold in the city. In addition to introducing the

\footnotetext{
Abdul Halim Abdul Karim, The Knowledge Based Economy in an Islamic System of Governance: The Khaldunian Perspective (PhD thesis, Universiti Brunei Darussalam, 2020).

2 Jeremy Black, The Power of Knowledge: How Information and Technology Made the Modern World (Yale University Press, 2014), 40.

3 Hyunhee Park, Mapping the Chinese and Islamic World: Cross-Cultural Exchange in Pre-Modern Asia (Cambridge University Press, 2012), 2526.
} 
art of papermaking to the Islamic world, the Chinese prisoners of war brought fine crafts such as silk weaving, gold, and silver working, as well as painting as Chinese craftsmanship was highly regarded in the Islamic community.

Information communication was further enabled through the advanced development of cartography by active travellers and geographers like al-Qazwini and al-Idrisi in the 7th century AH (12th century AD). There is a greater exchange of information as traders and scholars have increased confidence to travel more widely through the availability and accessibility of better maps. The fidelity of information exchanged was very high due to the adoption of sophisticated practices developed by hadith collectors. A story was authenticated through a chain of reliable transmitters and verified from multiple perspectives to ensure its veracity. ${ }^{1}$

There was a dynamic nature in which information was delivered and exchanged during this period. Information was transmitted using travellers or a postal system. In both forms of information communication, the information was either codified in written form on paper or transmitted verbally through travellers. Such exchanges ensured that information was delivered to individuals who can make use of the knowledge to produce valuable innovations. As a result, efficient communication and exchange of information led to major scientific developments and technological advancements. Any type of innovation-relation activities aimed at fulfilling the Maqāșid must have access to the relevant knowledge and efficient delivery of such information thus becomes one of the most essential ingredients for a culture of technological creativity.

\section{Ending Remarks}

Many historical accounts ascribed the Siege of Baghdad in 1258AD by the Mongols under Hulagu as the end of the 'Abbāsiyah period. This exogenous event disrupted many of the ingredients for a culture of technological creativity. Clear leadership evaporated when the incumbent Caliph al-Muta'sim was executed. This also led to the immediate loss of administration. Furthermore, institutions like the Bayt al-Hikmah were destroyed leading to further losses in knowledge-pursuing qualities and repositories of information. As a result,

Black, The Power of Knowledge, 41. 
the capacity to develop useful innovations dramatically declined. The 'Abbāsiyah caliphate ended abruptly after the siege and so did the first Islamic golden age.

In a span of over half a millennium, the Islamic world during the 'Abbāsiyah period provided many examples of how a culture of technological creativity can assist the community in carrying out the Maqāșid. In doing so, the Islamic world at that time was able to accrue massive wealth and achieved major technological advancements through scientific developments. Evident in the philosophical works of that time was the alignment of existing thoughts developed in other civilisations with Islamic theology. This led to significant advancements in the sciences which provided the new knowledge and information for making further advancements and producing new innovations.

Several examples were highlighted including al-Kindi's use of reason and mathematical accuracy to resolve prevalent issues of his time and al-Khwārizmi's mathematical advancements which helped spurred further research in astronomy and jurisprudence. The health sciences also benefitted from the translation efforts of Hunayn ibn 'Ishāq. These major scientific advancements did not only benefit the Islamic world. New knowledge and information created in the Islamic World which made the transition to Latin Europe shaped much of the European Renaissance that came later. ${ }^{1}$ This led to the Scientific Revolution around the beginning of the 16th century $A D$ which is still ongoing until this present day.

The translation movement played a very important role in scientific developments and technological advancements. It lowered the barrier of access to information by making knowledge easily available in Arabic. Furthermore, this facilitated the dissemination of information to individuals in the community who can use the knowledge to produce valuable innovations. One can ask what a similar translation movement would look like in the contemporary context experiencing disruptions due to IR4.0. Can such a movement simply be a digitalisation movement by making information easily available in digital form? Furthermore, what is the impact of digitalisation on trade, particularly in relation to the crossborder flow of digital data between sovereign nation-states? Following on from this, we can also ask how would digital market-based trading platforms operate? More importantly, how do we ensure the authenticity and veracity of the information exchange on such platforms?

1 George Saliba, Islamic Science and the Making of the European Renaissance (The MIT Press, 2007). 
The technological advancements made during the 'Abbāsiyah period offer some guidance in relation to the alignment of scientific developments with the theological principles of Islam. Scientific developments can lead to the production of innovations that create different forms of value in a parameter space governed by the Maqāșid framework. The five forms of valuecreation within the Maqāșid: Dīn, life, intellect, progeny, and wealth, can thus be appropriated accordingly for the innovations developed. By considering value-creation in this holistic manner, we ensure that that the value our innovations create is in alignment with the theological principles of Islam.

The overall character of this culture of technological creativity during the first Islamic golden age was one that was open to new and existing knowledge and information. It led to the many technological advancements made possible through major scientific developments. Such innovations were enabled through efficient means of communicating information. This ensured that information is delivered to individuals who could make use of the knowledge to produce valuable innovations. The activity of creating different forms of values using innovations thus thrived within a culture of technological creativity which was essential for the community to achieve the Maqāșid. We can learn much from this period and the different forms of value-creation outlined within the Maqāșid framework of governance can guide the manner in which we take charge of our scientific advancements and technological progress. 